\title{
The concept of moral education in Russian neo- Kantianism: correlation of philosophy and pedagogy
}

\author{
Pavel A. Vladimirov ${ }^{*}$ and Anastasia $V$. Lebedeva ${ }^{1}$ \\ ${ }^{1}$ RUDN, Faculty of Humanities and Social Sciences, Department of Ontology and Theory of \\ Knowledge, Moscow, Russia
}

\begin{abstract}
The article uncovers the key provisions of the moral education concept, formulated in the framework of Russian neo-Kantianism at the turn of the 19th-20th centuries but still remaining a poorly studied topic. Conducting historical-philosophical and comparative analysis, the authors reveal common intentions in the pedagogical ideas of Russian philosophers, which were based on rethinking the system of critical idealism of I. Kant and the methodology of German neo-Kantianism. Special attention is paid to the concept of moral education of S.I. Hessen, the theory of upbringing of A.V. Veideman, and the psychological pedagogy of M.M. Rubinstein. The article defines the key concepts and categories of Russian neo-Kantian pedagogy and methodological foundations, in particular, the teleological basis of the teaching and upbringing theory is revealed from the variety of author's and original ideas. The consistent uncovering and comparison of the pedagogical studies of Russian neo-Kantians allow revealing the general intention of their standpoints - focusing on the correlation of freedom and responsibility in the context of creating conditions for moral education. As a result, consideration of forming individual responsibility in the discourse of the correlation of arbitrariness and freedom is becoming the distinctive feature of the entire trend of Russian neo-Kantianism. The relevance of the study of this topic is due to the increasing need at present to identify the fundamental grounds for forming morality and responsibility in the continuity of the education, self-discipline, and training processes.

Keywords: critical philosophy, Russian neo-Kantianism, the theory of teaching and upbringing, freedom, responsibility, morality.
\end{abstract}

\section{Introduction}

Russian neo-Kantianism was formed in the history of Russian philosophy at the turn of the 19th-20th centuries. It was closely associated with the German neo-Kantian tradition and was within a single trend of the development of Kant's ideas in European philosophical thought [1]. The priority topics of Russian neo-Kantian researchers were not only a critical reflection on the theory of knowledge and the formation of a unified system of a holistic

\footnotetext{
*C Corresponding author: vladimirov_p_a@mail.ru
} 
worldview but also issues of pedagogy (for example, the polemic about national education [2]). In their works, M. Rubinstein, Hessen, and Veideman addressed the issue of pedagogical theory, unified with the transcendental philosophy.

With the obvious lack of uniformity in the views of the Russian neo-Kantians, their studies were similar in trend as well as were characterized by the common methodological foundations. The problem of approbation of human freedom is one of the fundamental problems in transcendental philosophy. The inseparability of the dignity of the individual and his freedom was indicated already in the works of Kant ("The concept of freedom is the stone of stumbling for all empiricists but at the same time the key to the loftiest practical principles (...)" [3]). Responsibility or normativity of behavior became a motive for the development of pedagogy and psychology based on the principles of critical analysis, as, for example, in the later works of A.I. Vvedensky [4] and the fundamental theory of general psychology of S.L. Rubinstein. Freedom cannot be lawlessness for a person who is aware of himself as a person with dignity, namely, aware of the idea of humanity. Undoubtedly, that the principles of moral law were already significantly interpreted in German neo-Kantianism, especially in the Baden School, but the problem remained a key issue [5]. Forming a sense of responsibility to oneself and others is the basis not only for the originality of the standpoint of German philosophers but also for the religious socialism of F.A. Stepun. In the pedagogical model of Russian neo-Kantianism, the problem of the correlation of freedom and responsibility becomes the leading idea for constructing arguments about the ways to achieve moral education. One can define the unity of the intention of the Russian neo-Kantians in matters of pedagogy as a moral education project. This problem has become the subject of contemporary research and has been reflected in posing the question concerning the moral foundations of education [6].

\section{Methods}

A distinctive feature of moral education consists in sequential uncovering of the individual's potential towards realizing their freedom and extent of responsibility. If freedom is understood exclusively as belonging to a single person, then the awareness of one's responsibility can only be achieved through external coercion. However, in such conditions, it becomes impossible to unlock the creative potential of the individual, while very freedom will be understood in a limited sense. This results in the contradiction between the norms of civil society and the desire for self-expression [7].

The neo-Kantian model of pedagogy, especially in its domestic interpretation, manifests a sharp difference from other theories of education and upbringing - freedom acts as a primate over any form of coercion and is not a self-evident concept as a given. The basis for the consistency of all stages of upbringing and education is Kant's system, which indicates the sequence of forming a critical attitude to oneself as a person, and one's cognitive abilities. In the pedagogical model of Russian neo-Kantianism, this viewpoint was enriched by comprehensive consideration of the personal becoming - from an early age and the appearance of the idea of one's own individuality to the formation of a self-aware personality. In the beliefs of Veideman, the extrapolation of the system of critical idealism to the process of education and formation of a responsible person is traced quite clearly [8].

Consistently revealing the process of socialization of a person from an early age to the period when a person is fully aware of the responsibility for their decisions and actions, Veideman develops his ideas in the same direction as the research of Hessen. In particular, it is worth noting the provision on the need for labor activity in the course of upbringing, which is defined as one of the integral elements of successful socialization [9]. Such ideas were indicated by Hessen in the "Fundamentals of pedagogy", and also have a certain 
analogy with the sociological research of A.S. Lappo-Danilevsky (the social significance of the volitional act and its awareness [10]).

The studies of the Russian neo-Kantians are mutually complemented, which is clearly seen in the arguments of Hessen and Stepun [11]. Less obvious is the consistency of the theories of B.A. Fokht and V.E. Seseman in the issue of how to achieve holistic knowledge. At that, one can find the disclosure of the final part of the moral education concept of Hessen in the works of Fokht, where the conditions for forming the ability of moral contemplation of the act of artistic creativity are considered [12].

\section{Results}

Creativity is a manifestation of a person's ability to create and discover new things, which could not be preceded in rational approbation. This approach to the understanding of creativity is directly revealed in the works of Fokht, who has set the task of finding a methodological basis for determining the role of the free act of contemplation in the system of transcendental philosophy. The search for a method for analyzing the pure contemplation of art objects and the self-expression of the creative potential of the individual can be extrapolated to Hessen's pedagogical model. In the work "Fundamentals of pedagogy: introduction to the applied philosophy", the presence of the ability to create is indicated as a manifestation of the formed autonomy of a person. Hessen, like Veideman, in contrast to Fokht, focuses on the manifestations of creativity in human practical activity, meaning primarily the expansion of science and socially useful activities. However, Hessen's works contain no obvious discrepancies with the understanding of creativity as a reflection of the ability of pure contemplation. Moreover, it can be found that the philosopher leaves the methodological aspect of the existence of a human predisposition to creativity without consideration. On the one hand, this situation is explained by the focus of the work on determining the conditions for the capabilities of pedagogy as part of applied philosophy, while on the other hand, Hessen does not conduct a philosophical analysis of the architectonics of human cognitive abilities but takes the general provisions of Kant's system of critical idealism as a basis.

According to Fokht, creativity is inextricably linked with the "moral sense of knowledge" and "pure feeling", while according to Hessen, it is associated with the morality of the individual, manifested in his freedom of autonomy. At that, both philosophers do not give significant differences in interpretation of the principle of ought with Kant's formulation. The achievement of morality is designated as a goal for a person who has realized the moral law (Hessen) or who has critically comprehended the meaning of pure contemplation (Fokht). At this point, the influence of German neo-Kantianism, in particular, the epistemological discourse "task-goal", is already clearly manifested [13]. Turning to the concept of moral education, one can assume that one of the manifestations of the moral personality is mastering creative ability and "creating" objects of pure contemplation.

For Hessen, the presence of autonomy and motivation to expand the significance of science in culture serves as the example of the manifestation of personality formedness. Socially beneficial activities as well as science are primarily related to the spiritual life of the culture. The philosopher criticizes the existing pedagogical approaches because of the excessive simplification of the teaching and upbringing process that inevitably leads to fragmentary implementation of the moral principles of education. The limitations of the training orientation only to the formation of applied skills were already pointed out by Kant, while P.G. Natorp has shown the ambiguity of utilitarian pedagogy for the development of social relations [14]. One of the negative consequences, according to the 
German neo-Kantian, is excessive individualization in the social medium. The ideas of M. Rubinstein are in the same context as the ideas of Hessen.

The position of M. Rubinstein in the most general form is expressed in the construction of psychological pedagogy on the principles of philosophy [15]. The latter deals with the reflection on the fundamental issues of life and psychology and sets regulatory principles to form conditions for the upbringing and molding a personality already within the framework of pedagogy [16]. Thus, the sequence of the process is formed from the general, that is, the reflection of the worldview, to the specific - a model for solving the problems of upbringing and education of the individual. At that, the Russian philosopher always points to the role of philosophy in establishing general principles and goals for the education and upbringing of the individual, while the solution of specific pedagogical tasks is the area of pedagogical consideration, supplemented by psychological studies of the individual. It should be noted that unlike another well-known philosopher, who became one of the founders of classical psychology, that is, S. Rubinstein, M. Rubinstein holds the position of the fundamental inseparability of the theoretical foundations of psychology from applied psychology. As a result, practical and applied activity always accompanies theoretical constructions in psychology, which is extrapolated by the philosopher to the field of pedagogy.

In the article "Pedagogika ili psikhologicheskaya pedagogika? (Pedagogy or pedagogical psychology?)" published in the collection "Voprosy filosofii i psikhologii (Issues of Philosophy and Education)" in 1912, M. Rubinstein outlined the specifics of philosophical reflection on the problems of education and upbringing [15]. It is noteworthy that the introductory section of the article shows the difference between the "old pedagogy" and the "new science" of education and upbringing [16]. Thus, the author sets a context of the formation of pedagogy on an interdisciplinary ground, where philosophy becomes a necessary methodological and goal-setting basis. The Russian neo-Kantian denotes insurmountable contradictions in the one-sided interpretation of education and upbringing only from the perspective of experimental or applied psychology. The learning process is always more than a simple set of rules and psychophysical responses, since it involves, in addition to the direct acquisition of skills, a cultural education, familiarization with tradition, and morality.

However, philosophical approach to the problems of education should contain practical and applied ideas, which are then implemented in specific pedagogical activities. In general, the position of $\mathrm{M}$. Rubinstein is closer to the contemporary understanding of the education system as a public institution, where the key aspect is forming targeted training program, and then gradually building mechanisms to achieve the educational goal.

\section{Discussion}

For the entire neo-Kantian movement, both German and Russian, the individual and his freedom were an integral part of the philosophy system. Accordingly, pedagogy was conceived as part of a philosophical system, where the personality formation process was revealed most fully. In Russian studies, as in the German neo-Kantian tradition, pedagogy is a consequence of the philosophy system, its concretization under certain specified conditions. One can draw an analogy with the Marburg School, where the functional meaning of philosophy is reflected in the setting of a "task" and identifying a "goal" for subsequent cognitive reflection or "delineation" of the research subject and object. Pedagogy is built on philosophy, its methods and techniques include psychological research in their content, but the organization of the educational process is the true essence of the very pedagogy. 
The pedagogical theory of M. Rubinstein is revealed through the example of the historical and philosophical analysis of the collection "On the meaning of life" and several articles, especially "Pedagogy or pedagogical psychology?" The collection "On the meaning of life" provides an exhaustive description of the relationship between pedagogy and philosophy within the framework of the correlation of the philosophy of life and the philosophy of education, while the reasoning logic is built within the framework of the neoKantian methodology. Although it becomes obvious that M. Rubinstein overcomes the German tradition of neo-Kantianism, moving on to the issue of the ultimate foundations of life, the general intentions remain. While in the Baden School the concept of life was also considered within the system of cultural problems [17], the Russian philosopher poses questions about the ways of reliability of philosophical reflection on the meaning or deep foundation of exactly human life, his existence in the world of the known and unknown. Such ideas were typical for neo-Kantianism in general that was reflected in the studies of V.N. Belov and J.G. Karagod [7].

\section{Conclusion}

The main meaning of the concepts of "creativity" and "freedom" in the pedagogical model of Russian neo-Kantianism can be summarized in two provisions.

1. In neo-Kantianism, freedom is the opposite of arbitrariness (that is, a state of savagery) and is defined as an integral component of the individual, who is aware of the responsibility to the surrounding individuals and himself. For pedagogy, the freedom of the individual acts as a primate with respect to forms of coercion or restriction that determines the need for an individual approach to education.

2. The priority task of education and the function of pedagogy, as part of practical philosophy, is to create conditions for forming a personality, free within the framework of his responsibility and morals. The only limit of freedom in its full meaning can be the prescriptions of reason, thus, the individual is guided by the systematization and critical rationalization of his actions and motives.

At the end of the consideration of the concept of moral education as a general intention of the pedagogical theories of the Russian neo-Kantians, one should note that some studies are still not found and waiting for publication. Let outline just some of them that relate to the issues of forming the concept of moral education. These are Hessen's works, presumably written in Polish "On the contradictions and unity of education" (1938) and "The structure and content of the contemporary school" (written presumably from 1938 to 1939), which were lost during the outbreak of the war. The works of Fokht were published for the first time in a systematic presentation due to the research work of N.A. Dmitrieva $[12,18]$. It is worth noting the translations and editions of archival material, in particular, the articles of Seseman and Veideman. Based on these facts, it can be argued that it is now that conditions are created for a comprehensive and systematic consideration of the legacy of neo-Kantianism that directly relates to the reconstruction and actualization of the pedagogical model of Russian neo-Kantianism as part of the general history of the development of the Russian pedagogical school.

\section{References}

1. V.N. Belov, Kantovsky Sbornik [Kantian Journal], 1(47), 59-65 (2014). https://doi.org/10.5922/0207-6918-2014-1-4

2. N.A. Dmitriyeva, Kantovsky Sbornik [Kantian Journal], 1(36), 66-89 (2017). https://doi.org/10.5922/0207-6918-2017-1-6 
3. I. Kant, Kritika chistogo razuma. Kritika prakticheskogo razuma. Kritika sposobnosti suzhdeniya [Critique of pure reason. Critique of practical reason. Critique of the power of judgment] (Eksmo, Moscow, 2018)

4. A.I. Vvedensky, Psikhologiya bez vsyakoy metafiziki [Psychology without any metaphysics] (Kniga po trebovaniyu, Moscow, 2013)

5. W. Windelband, Izbrannoye: dukh i istoriya [Selected: spirit and history] (Yurist, Moscow, 1995)

6. W. Althof, M.W. Berkowitz, Journal of Moral Education, 35(4), 495-518 (2006). https://doi.org/10.1080/03057240601012204

7. V.N. Belov, J.G. Karagod, Advances in Social Science, Education and Humanities Research, 142, 12-15 (2017). https://doi.org/10.2991/icelaic-17.2017.4

8. A.V. Veideman, Myshleniye i bytiye (logika dostatochnogo osnovaniya) [Thinking and being (Logic of sufficient reason)] (Salamandra, Riga, 1927)

9. S.I. Hessen, Osnovy pedagogiki: vvedeniye v prikladnuyu filosofiyu [Bases of pedagogy: an introduction to applied philosophy] (Shkola-Press, Moscow, 1995)

10. A.V. Malinov, Sotsiologicheskiye issledovaniya A.S. Lappo-Danilevskogo [Social studies by A.S. Lappo-Danilevsky] (RHGA, Saint Petersburg, 2017)

11. A. Chernyheva, A. Kostikova, Advances in Social Science, Education and Humanities Research, 283, 771-774 (2018). https://doi.org/10.2991/cesses-18.2018.170

12. B.A. Fokht, Izbrannoye (iz filosofskogo naslediya) [Selected (from the philosophical heritage)] (Progress-Traditsiya, Moscow, 2003)

13. V.N. Belov, Russian Studies in Philosophy, 54, 395-407 (2016). https://doi.org/10.1080/10611967.2016.1290415

14. P. Natorp, Izbrannyie raboty [Selected works] (Territoriya Budushchego, Moscow, 2006)

15. M.M. Rubinstein, Pedagogicheskiye idei Platona [Pedagogical ideas of Plato], in Voprosy filosofii i psikhologii [Issues of philosophy and education], Volume 124(4) (Tipo-litografiya Vysochayshe utverzhdennogo tovarishchestva I.N. Kushnerev i Ko, Moscow, 1914)

16. M.M. Rubinstein, Pedagogika ili psikhologicheskaya pedagogika? [Pedagogy or pedagogical psychology?], in N.I. Grot (Ed.), Voprosy filosofii i psikhologii [Issues of philosophy and education], Volume 113(3) (Tipo-litografiya Vysochayshe utverzhdennogo tovarishchestva I.N. Kushnerev i Ko, 1912)

17. H. Rickert, Filosofiya zhizni [Philosophy of life] (Nika-Tsentr, Kyiv, 1996)

18. N.A. Dmitrieva, Russian Studies in Philosophy, 54(5), 378-394 (2016).

https://doi.org/10.1080/10611967.2016.1290414 